\title{
Study of deoxidization process of CsI melt by the action of "Zr-Pt" galvanic couple
}

\author{
V.L.Cherginets ${ }^{1}$, T.P.Rebrova ${ }^{1}, Y_{. N . D a t s k o}{ }^{1}$, \\ A.L.Rebrov ${ }^{1}$, P.V.Mateychenko ${ }^{2}$ \\ ${ }^{1}$ Institute for Scintillation Materials, STC "Institute for Single Crystals", \\ National Academy of Sciences of Ukraine, \\ 60 Nauky Ave., 61001 Kharkiv, Ukraine \\ ${ }^{2}$ Institute for Single Crystals, National Academy of Sciences of Ukraine, \\ 60 Nauky Ave., 61001 Kharkiv, Ukraine
}

Received July 20, 2016

The course of removal of oxide ion admixtures (deoxidization) from molten cesium iodide using galvanic couple "zirconium-platinum" at $973 \mathrm{~K}$ was studied by a potentiometric method using a membrane oxygen electrode $\mathrm{Pt}\left(\mathrm{O}_{2}\right) \mid \mathrm{YSZ}$ (YSZ - yttria stabilized zirconia) as an indicator one for the detection of current and equilibrium concentrations of $\mathrm{O}^{2-}$. The running of the deoxidization in both cases is subjected to kinetics of $2^{\text {nd }}$ order process with respect to $\mathrm{O}^{2-}$ and the rate constant is as $(3.07 \pm 0.31) \cdot 10^{6} \mathrm{~kg} \cdot \mathrm{mol}^{-1} \cdot \mathrm{min}^{-1} \cdot \mathrm{cm}^{-2}$ for the galvanic couple. Surface capacity of the galvanic couple with respect to oxide ions was estimated as $7.6 \cdot 10^{-4} \mathrm{~mol} \cdot \mathrm{cm}^{-2}$. The destruction and fixation of oxygen-containing admixtures in the case of the galvanic couple occur more intensively that in the case of pure zirconium and "Zr-Pt" combination is more promising agent for deep purification of growth halide melts.

Keywords: melt processing, cesium iodide, deoxidization, zirconium, rate constant, surface capacity.

Представлены результаты исследования процесса очистки расплава йодида цезия от кислородсодержащих примесей с помощью гальванической пары "Zr-Pt" при 973 К. Для определения текущей и равновесной концентрации $O^{2-}$ использовали потенциометрическую ячейку с мембранным кислородным әлектродом $\mathrm{Pt}\left(\mathrm{O}_{2}\right) \mid \mathrm{YSZ}\left(\mathrm{YSZ}-0.9 \mathrm{ZrO}{ }_{2}+0.1 \mathrm{Y}_{2} \mathrm{O}_{3}\right)$. Процесс раскисления протекает по уравнению II порядка по отношению к $\mathrm{O}^{2-}$, соответст-

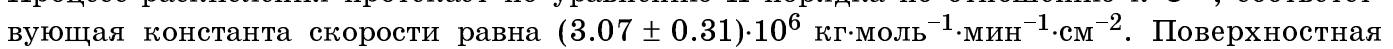
емкость циркония по $\mathrm{O}^{2-}$ составляет $7.6 \cdot 10^{-4}$ моль $\mathrm{cm}^{-2}$. Процесс разрушения и связывания кислородсодержащих примесей при использовании гальванической пары протекает более интенсивно,чем при использовании чистого циркония, и она является более перспективным агентом для глубокой очистки ростовых галогенидных расплавов.

Вивчення процесу розкислення розтопу CsI дією гальванічної пари " $\mathrm{Zr}-\mathrm{Pt}$ ". В.Л.Чергинець, Т.П.Реброва, Ю.М.Дацько, О.Л.Ребров, П.В.Матейченко.

Наведено результати дослідження процесу очистки розтопу йодиду цезію від оксигенвмісних домішок за допомогою гальванічної пари "Zr-Pt" при 973 К. Для визначення поточної і рівноважної концентрації $\mathrm{O}^{2-}$ використано потенціометричну комірку 3 мембранним оксигеновим електродом $\mathrm{Pt}\left(\mathrm{O}_{2}\right) \mid \mathrm{YSZ}\left(\mathrm{YSZ}-0.9 \mathrm{ZrO}_{2}+0.1 \mathrm{Y}_{2} \mathrm{O}_{3}\right)$. Перебіг процесу розкислення відбувається у відповідності з рівнянням II порядку відносно $\mathrm{O}^{2-}$, кон-

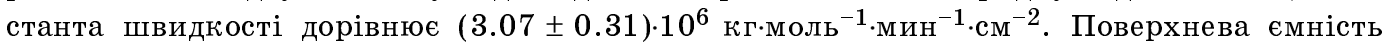
цирконію відносно $\mathrm{O}^{2-}$ оцінюється у $7.6 \cdot 10^{-4}$ моль $\mathrm{cm}^{-2}$. Процес руйнування і зв'язування оксигенвмісних домішок при використанні гальванічної пари протікає більш інтенсивно ніж при використанні чистого цирконію, вона є більш перспективним агентом для глибокої очистки ростових галогенідних розтопів. 


\section{Introduction}

Single crystals of pure cesium iodide are widely used as one of the best materials for optical details transparent for IR radiation [1]. Another well-known application of undoped Csl is connected with high-energy physics: it is used as scintillator stable under action of very intensive fluxes of high-energy particles [2]. For both Csl applications oxygen-containing admixtures (mainly, hydroxide and carbonate) are very undesirable since their inclusion into the crystals leads to appearance of absorption bands in IR region. Ditto, the presence of carbonates or hydroxides makes the single crystals hygroscopic and hydrogen-containing ions formed because of crystal hydrolysis:

$$
\mathrm{CO}_{3}^{2-}+\mathrm{H}_{2} \mathrm{O} \rightarrow \mathrm{HCO}_{3}^{-}+\mathrm{OH}^{-}
$$

are very prone to radiolysis with the formation of coloring centers worsening the transparency and performance of the crystals [3]. Therefore, the problem of deep deoxidization of Csl melt is very urgent for creation of halide single crystals of excellent optical quality.

As is known, oxygen-containing admixtures enter into halide raw for crystal growth in all the stages of its preparation: synthesis of initial chemicals, heating in vacuum, melting and immediately following growth procedure. Naturally, the purification of the melt immediately before the growth process should be the most efficient. Although there are few ways of purification of Csl in molten state some of them, e.g. purification by gaseous hydrogen iodide, cannot be recommended for industrial purposes because of great corrosion activity of the halogenating agent.

Treatment of iodide melts by metals-getters is considered among the most convenient routines since such a treatment is not accompanied with formations of aggressive volatile substances or appreciably dissolved admixtures in the melts. Ditto, this way of treatment is waste-free since the purification process is not accompanied with emission of pollutants in environment. Zaslavsky [4] used for this purpose spongy titanium. According to the analytical data there was a definite decrease of some admixtures in wastes of $\mathrm{Csl}\left(\mathrm{Tl}^{+}\right.$, borates and sulfates) down to mass fraction of $(2 \div 4) \cdot 10^{-7}$. Nevertheless, this level of growth melt purity is not enough for manufacturing of the high-quality single crystals meeting nowadays requirements.

Following development of this approach was initiated in our paper [5] where metallic zirconium was used for removal of oxygen-containing admixtures.The essence of the purification process consists in the running of the following reaction:

$$
\mathrm{Zr} \downarrow+2 \mathrm{Cs}_{2} \mathrm{O} \rightarrow \mathrm{ZrO}_{2} \downarrow+4 \mathrm{Cs} .
$$

The well-known for metallurgy rule says that the equilibrium of reaction of a metal with oxide of other metal (crucible) in condensed phase is shifted to the formation of oxide possessing lower enthalpy of formation per one oxygen atom $\left(\Delta H_{\mathrm{MeO}_{\mathrm{n}}} / n\right)$ [6]. The application of the said rule for

$$
\begin{aligned}
& \mathrm{Cs}_{2} \mathrm{O}\left(\Delta H_{\mathrm{Cs}_{2} \mathrm{O}}^{f}=-317 \mathrm{~kJ} \cdot \mathrm{mol}^{-1}\right), \\
& \mathrm{TiO}_{2}\left(\Delta H_{\mathrm{TiO}_{2}}^{f} / 2=-506 \mathrm{~kJ} \cdot \mathrm{mol}^{-1}\right), \\
& \mathrm{ZrO}_{2}\left(\Delta H \mathrm{ZrO}_{2}^{f} / 2=-550.2 \mathrm{~kJ} \cdot \mathrm{mol}^{-1}\right) \text { and, }
\end{aligned}
$$

e.g. $\mathrm{CaO}\left(\Delta H_{\mathrm{CaO}}^{f}=-635 \mathrm{~kJ} \cdot \mathrm{mol}^{-1}\right)$ predicts that $\mathrm{Zr}$ should be more effective deoxidizing agent for Csl melt containing oxide ions than $\mathrm{Ti}$, and this actually takes place [5]. Both metals-getters cannot be used, e.g., for purification of $\mathrm{CaCl}_{2}$ from oxide ion traces, moreover, $\mathrm{ZrO}_{2}$ is reduced by $\mathrm{Ca}$ in $\mathrm{CaCl}_{2}$-containing melts [7],i.e.reaction

$$
\mathrm{ZrO}_{2} \downarrow+2 \mathrm{Ca} \rightleftarrows \mathrm{Zr} \downarrow+2 \mathrm{CaO}
$$

runs rightwards but not to the left side.

Returning to $\mathrm{Zr}-\mathrm{Csl}\left(\mathrm{O}^{2-}\right)$ system it should be noted that the use of pure zirconium gave possibility to decrease of the total concentration of oxide ion in the melt only by a factor of 6 after long-term treatment (ca. $3 \mathrm{~h}$ ) [5]. Of course, the way of purification should be more attractive after finding ways providing higher efficiency and shortening the time of the melt treatment. One of such ways consists in entering of "metal-getter-noble metal" galvanic couple into the treated melt. As is known, in this case the rate of corrosion (Eq. 1) will increase and the reduction process will run at the surface of nobler metallic component that can compensate the passivation of the getter surface.

However, such a simple approach did not tested yet, although it could be used for other halide melts which preliminary purification from oxides before the main technological process would be rather desirable. The investigation of efficiency of such a galvanic couple formed by zirconium and 
platinum is the goal of the present study. Since the rule presented in [6] does not impose constrains on anion composition of purified halide melts that results obtained for Csl melt can be extended to the melts of other alkali metal halides.

\section{Experimental}

For studying the process of " $(\mathrm{Zr}+\mathrm{Pt})-$ Csl $\left(\mathrm{O}^{2-}\right)$ " interaction in situ we used the potentiometric cell with a membrane oxygen electrode $\mathrm{Pt}\left(\mathrm{O}_{2}\right) \mid \mathrm{YSZ}$ (where $\mathrm{YSZ}$ the $0.9 \mathrm{ZrO}_{2}-0.1 \mathrm{Y}_{2} \mathrm{O}_{3}$ solid electrolyte ceramics):

$$
\operatorname{Ag}\left|\mathrm{Ag}^{+}(x=0.03), \mathrm{Csl} \quad: \quad: \mathrm{Cs}, \mathrm{O}^{2-}\right| \mathrm{YSZ} \mid \mathrm{Pt}\left(\mathrm{O}_{2}\right) \text {. }
$$

This cell was first calibrated with known weights of $\mathrm{KOH}$ which served as a donor of oxide ions since its dissociation in molten salts:

$$
2 \mathrm{OH}^{-} \rightarrow \mathrm{H}_{2} \mathrm{O} \uparrow+\mathrm{O}^{2-}
$$

occurred completely in dry inert atmosphere. This gave us possibility to obtain the dependence of emf $(E)$ of cell (4) on $p O$ $\left(p O \equiv-\log m_{\circ}{ }^{2-}\right)$, where $m_{\circ}{ }^{2-}$ the equilibrium molality of oxide ions in molten Csl).

Cesium iodide supplied by Aldrich with the mass fraction of the main substance of 0.99999 (kept for a year) was used for the melt preparation. Total concentration of oxygen-containing admixtures in the salt after the melting was $c a \cdot 2-5 \cdot 10^{-4} \mathrm{~mol} \cdot \mathrm{kg}^{-1}$.

$\mathrm{Zr}$ small cylinder with platinum contact was obtained from the $\mathrm{Zr}$ rods with the mass fraction of $\mathrm{Zr}$ equal to 0.9999 and chemically pure platinum wire. Before the experiment $\mathrm{Zr}$ was treated by diluted $\mathrm{HCl}$ (mass fraction of $\mathrm{HCl}$ is 0.20 ) to remove the traces of other metals and contaminations. The surface area of $\mathrm{Zr}$ cylinders was $c a$. $0.92 \mathrm{~cm}^{2}$.

The calibration of cell (4) was performed by entering of weighted amounts of $\mathrm{KOH}$ into Csl melt heated to $973 \mathrm{~K}$. Then equilibrium emf value $(E)$ was determined by measurement of current emf value (each 5 min, compensational scheme, Poggendorff's bridge) until three sequential measurements gave the same value. According to Eq. (5) two moles of $\mathrm{KOH}$ corresponded to one mole of oxide ion. Similarly to data of [5] the calibration plot consisted of two linear sections with slopes, approximately equal to $1.15 R T / F$ at low oxide ion concentrations:
$E(V)=-0.0356+0.0976 \cdot p O, E>0.144 \mathrm{~V}(6)$

and $2.3 R T / F$ at high oxide ion concentrations:

$$
E(V)=-0.338+0.253 \cdot p O, E<0.144 \mathrm{~V} .
$$

These equations were further used for recalculation of the emf values obtained at the deoxidization process into $\mathrm{m}_{\mathrm{O}}{ }^{2-}$ ) and $p O$.

The deoxidization process was studied by placing a $\mathrm{Zr}$ cylinder with $\mathrm{Pt}$ contact into molten Csl $(150 \mathrm{~g})$. After 5 min keeping we measured the dependence of emf versus time (each 1-10 min dependently on rate of the emf increase) up to the stabilization of emf. Then a weight of $\mathrm{KOH}$ was added to the melt and the next emf dependence was obtained. The procedure was finished when the getter did stop reacting with oxide ions (no directed emf changes with the time).

\section{Results and discussion}

A study of interaction of pure zirconium with oxygen-containing admixtures in molten Csl was described in details in [8]. The surface capacity of the used $\mathrm{Zr}$ getter with respect to oxygen is $4.2 \cdot 10^{-5} \mathrm{~mol} \cdot \mathrm{cm}^{-2}$. As it has been noted above, the concentration of oxide ion during the purification process is decreased by a factor of 6 , i.e., the deoxidizing action of the getter on Csl melt is effective enough and the time of the treatment should be $c a .3 \mathrm{~h}$. The deoxidization runs according to kinetics of $2^{\text {nd }}$ order process with respect to $\mathrm{O}^{2-}$, the rate constants is $80 \pm 8 \mathrm{~kg} \cdot \mathrm{mol}^{-1} \cdot \mathrm{min}^{-1} \cdot \mathrm{cm}^{-2}$.

Now let us consider the interaction of "Zr-Pt" galvanic couple with oxygen-containing admixtures in molten cesium iodide. As is known, the action of a galvanic couple consists in the fact that if two contacting metals are placed in aggressive medium, more active metal is subjected to corrosion. Namely, in our case:

$$
\mathrm{Zr}^{0}-4 \bar{e} \rightleftarrows \mathrm{Zr}^{4+}
$$

and it can dissolve in aggressive liquids (ionic halide melts). Electrons arising at this process pass into more noble metal (Pt) and take part in reduction processes at its surface. If the reduction process results in formation of insoluble products of the reduction, they are formed near the surface of the more noble metal and do not affect processes running at the surface of more active metal. Nevertheless, in our case sur- 
face of zirconium is sequentially passivized be cause of formation of insoluble $\mathrm{ZrO}_{2}$ :

$$
\mathrm{Zr}^{4+}+2 \mathrm{O}^{2-} \rightarrow \mathrm{ZrO}_{2} \downarrow
$$

The latter reaction should result in additional contiguous retarding the main process. Let us consider the experimental data. Typical dependences of $p O$ vs. time of the deoxidization process are presented in Fig. 1.

As is seen, addition of the getter to the initial molten CsI leads to relatively fast increase of $p O$ up to a plateau at 8.13 (Fig. 1, curve 1) that corresponds to $7.4 \cdot 10^{-9} \mathrm{~mol} \cdot \mathrm{kg}^{-1}$ of $\mathrm{O}^{2-}$. Comparing this residual concentration with the action of pure zirconium getter was used without the galvanic pair $\left(p O=4.03, m_{\circ}{ }^{2-}=9.5 \cdot 10^{-5}\right)$ one can conclude that the addition of platinum contact results in increase of efficiency of the purification process and the residual concentration of oxide ion decreases by a factor of $c a .10^{4}$.

After the first addition of $\mathrm{KOH}$ (Fig. 1, curve 2) the increase of $p O$ is also observed and its final value is equal to 8.13. This gives the evidence that the surface of $\mathrm{ZrO}$ is not passivized completely. Nevertheless, the rate of the deoxidization process becomes slower that takes place due to reduction of the active surface of the getter.

The second addition of potassium hydroxide leads to complete passivation of the getter surface since $p O$ increase stops at value of 4.03 (Fig. 1, curve 3) and the following adding of $\mathrm{KOH}$ is not accompanied with interaction, which can be indicated by app reciable $p O$ rise (Fig. 1 , curve 4 ).

To perform quantitative estimations of the deoxidization process in this case it is necessary, in the first turn, to find the surface capacity of zirconium getter with respect to oxide ions. The data presented in Table should be helpful for this purpose, here $w_{\mathrm{KOH}}$ is the current mass of added $\mathrm{KOH}, \sum w_{\mathrm{KOH}}$ the total mass of $\mathrm{KOH}, \sum n_{\mathrm{O}^{2}}^{0}$

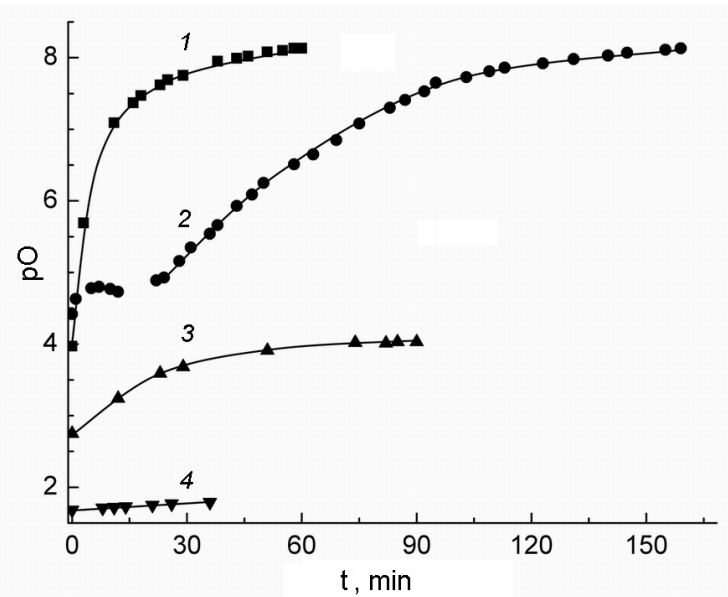

Fig. 1. The dependences of $p O$ versus time $(t)$ for processes of deoxidization of molten Csl by $\mathrm{Zr}-\mathrm{Pt}$ galvanic pair at $973 \mathrm{~K}$ : pure melt (1) and sequential additions of $0.0153 \mathrm{~g}$ (2), $0.442 \mathrm{~g} \mathrm{(3)}$ and $0.1250 \mathrm{~g} \mathrm{(4)}$ of $\mathrm{KOH}$. The mass of the melt is $150 \mathrm{~g}$.

the total quantity of added oxide ions together with the admixtures $\left(9 \cdot 10^{-5}\right.$ mole $)$ in $150 \mathrm{~g}$ of the melt, $p O_{\infty}$ the $p O$ value at the "plateau" section, $m_{0}{ }^{2-}$ the corresponding molality of $\mathrm{O}^{2-}, n_{\infty, \mathrm{O}^{2-}}$ the number of moles of $\mathrm{O}^{2-}$ after the finishing of the deoxidization process and $\alpha$ is the degree of the surface filling.

Since the second addition of $\mathrm{KOH}$ results in complete filling of the getter surface, here $\alpha$ is equal to 1 . A number of moles of fixed $\mathrm{O}^{2-}\left(n_{\mathrm{O}}{ }^{2-}, f i x\right)$ is equal to:

$$
\begin{gathered}
n_{\mathrm{O}^{2-}}, f i x \\
=\sum n_{\mathrm{O}^{2-}}^{0}-n_{\infty, \mathrm{O}^{2-}}= \\
=7.11 \cdot 10^{-4}-1.4 \cdot 10^{-5}=6.97 \cdot 10^{-4} .
\end{gathered}
$$

Knowing the getter surface area $\left(S_{Z r}=\right.$ $0.92 \mathrm{~cm}^{2}$ ) we can estimate the surface capacity of $\mathrm{Zr}$ getter in $\mathrm{Zr}-\mathrm{Pt}$ galvanic couple $\left(W_{\mathrm{Zr}-\mathrm{Pt}}\right)$ :

\begin{tabular}{|c|c|c|c|c|c|c|}
\hline \multicolumn{3}{|c|}{ Initial quantities } & \multicolumn{3}{|c|}{ Equilibrium quantities } & \multirow[t]{2}{*}{$\alpha$} \\
\hline$w_{\mathrm{KOH}}, \mathrm{g}$ & $\sum w_{\mathrm{KOH}}, \mathbf{g}$ & $\sum n_{\mathrm{O}^{2-}}^{0}, \mathrm{~mol}$ & $p O_{\infty}$ & $m_{\mathrm{O}^{2-}}, \mathrm{mol} \cdot \mathrm{kg}^{-1}$ & $n_{\infty, \mathrm{O}^{2-}}, \mathrm{mol}$ & \\
\hline- & - & - & $9 \cdot 10^{-5}$ & 8.13 & $7.4 \cdot 10^{-9}$ & $1.1 \cdot 10^{-9}$ \\
\hline 0.0153 & 0.0153 & $2.27 \cdot 10^{-4}$ & 8.13 & $7.4 \cdot 10^{-9}$ & $1.1 \cdot 10^{-9}$ & 0.325 \\
\hline 0.0442 & 0.0695 & $7.11 \cdot 10^{-4}$ & 4.03 & $9.2 \cdot 10^{-5}$ & $1.4 \cdot 10^{-5}$ & 1.0 \\
\hline 0.1250 & 0.1945 & $1.83 \cdot 10^{-3}$ & 1.77 & - & - & - \\
\hline
\end{tabular}

Table. Initial data for estimation of the surface capacity of zirconium getter in galvanic couple

"Zr-Pt" with respect to oxide ions in molten Csl at $973 \mathrm{~K}$ 


$$
\begin{aligned}
W_{\mathrm{Zr}-\mathrm{Pt}}= & n_{\mathrm{O}^{2-}, \mathrm{fix}} / S_{\mathrm{Zr}}=\left(6.97 \cdot 10^{-4}\right) / 0.92 \approx \\
& \approx 7.6 \cdot 10^{-4} \mathrm{~mol} \cdot \mathrm{cm}^{-2} .
\end{aligned}
$$

This value exceeds similar parameter estimated for $\mathrm{Zr}$ getter acting without the galvanic pair by a factor of ca. 18 [8] that underlines the obvious advantage of the use of galvanic couple for the melt deoxidization. Concerning this work this parameter gives us possibility to calculate final value of $\alpha$ after each $\mathrm{KOH}$ addition using the following formula:

$$
\alpha=\frac{\sum n_{\mathrm{O}^{2-}}-n_{\infty, \mathrm{O}^{2-}}}{W_{\mathrm{Zr}-\mathrm{Pt}}}
$$

After calculating $\alpha$ we can proceed to estimation of the kinetic characteristics of the deoxidization. Since at first and second $\mathrm{KOH}$ additions there are considerable increase of $p O$ we can consider that the deoxidization process in inclined sections runs irreversibly. Therefore, its running should be subjected to the known kinetic regularities for simple reactions.

Since we can determine current concentration of only oxide ion the running of the process can be described by pseudo-order, i.e., power in which oxide ion concentration enters in the kinetic equation of the following general form:

$$
w=k \cdot m_{\mathrm{O}^{2-}}^{n},
$$

where $k$ the rate constants of the purification process.

In the case of $n=1$ (the first pseudoorder) the dependence of current $(c)$ concentration from the initial one $\left(c_{0}\right)$ and time $(t)$ is described by the following equations:

$$
c=c_{0} \cdot \exp (-k t) \text { or } \ln c=\ln c_{0}-k t .
$$

This means that the dependence of logarithm of concentration from time should be linear. Nevertheless, $p O$-t dependences $\left(p O \equiv-\log m_{\mathrm{O}}{ }^{2-}\right)$ being logarithmic are not linear for the first three additions of $\mathrm{KOH}$ that forces to reject the assumption about the 1st pseudo-order. Contrary, dependences $\left(m_{\mathrm{O}^{2-}}\right)^{-1}=f(t)$ (which linearity confirms the second kinetic order):

$$
c^{-1}=c_{0}^{-1}+k t
$$

presented in Fig. 2 are linear ( $r_{x y} \geq 0.99$ ).

These speculations help us to determine the pseudo-order of interaction "Zr-oxygen admixtures" as second one. The obtained result

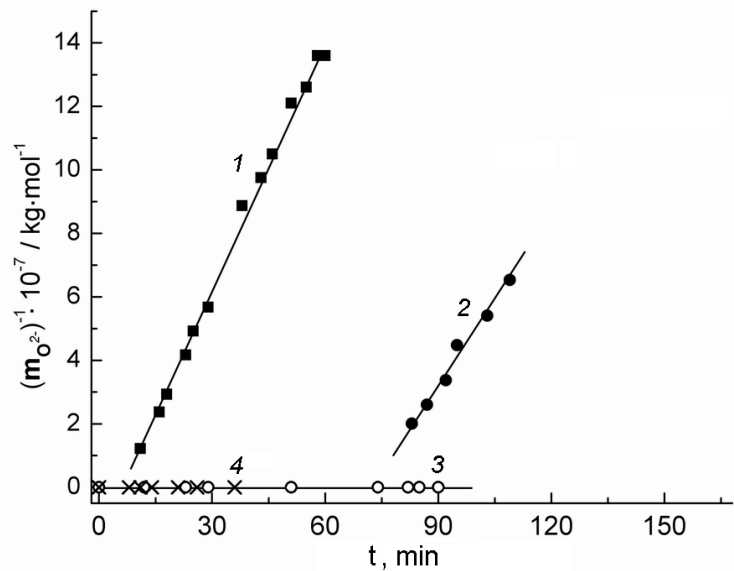

Fig. 2. The dependences of $\left(m_{\mathrm{O}}{ }^{2-}\right)^{-1}=f(t)$ for process of deoxidization of molten Csl by $\mathrm{Zr}-$ Pt galvanic pair at $973 \mathrm{~K}$ : pure melt (1) and sequential additions of $0.0153 \mathrm{~g}(2), 0.442 \mathrm{~g}$ (3) and $0.1250 \mathrm{~g} \mathrm{(4)}$ of $\mathrm{KOH}$.

completely corresponds to stoichiometry of reaction (2) that leads to formation of $\mathrm{ZrO}_{2}$. On the other hand such value of pseudoorder can confirm that reaction (2) is the limiting stage of the process. It should be noted, however, that the deoxidization by getter is complicated by changes of active surface of zirconium which sequentially reduces with the decrease of oxide ion concentration in the melt. The kinetic equation for such a case can be written by such a manner:

$$
\begin{gathered}
w=k S_{\mathrm{Zr}}(1-\alpha) \cdot\left(m_{\mathrm{O}^{2-}}\right)^{2}= \\
=S_{\mathrm{Zr}}[k(1-\alpha)] \cdot\left(m_{\mathrm{O}^{2-}}\right)^{2},
\end{gathered}
$$

where $w$ the reaction rate, $k$ the rate constant.

To facilitate our calculations of the rate constant we chose for estimation points which $p O$ values exceeded 6 , since in this case (initial $p O$ was $c a$. 4) approximately 99 per cent of the added oxide ions was fixed by zirconium and during further interaction $\alpha$ value was practically constant and equal to final $\alpha$ for each $\mathrm{KOH}$ addition. Just owing to this reason plots 1 and 2 depicted in Fig. 2 starts from times 10 and $80 \mathrm{~min}$, respectively. The dependences 1 and 2 in Fig. 2 can be approximated by the following equations:

$$
\begin{gathered}
\left(m_{\mathrm{O}^{2-}}\right)^{-1}= \\
=-1.7( \pm 5) \cdot 10^{7}+2.64( \pm 0.1) \cdot 10^{6} \cdot t
\end{gathered}
$$

and 


$$
\begin{gathered}
\left(m_{\mathrm{O}^{2-}}\right)^{-1}= \\
=-1.26( \pm 0.3) \cdot 10^{8}+1.76( \pm 0.3) \cdot 10^{6} \cdot t,
\end{gathered}
$$

respectively. In both cases the reproducibility of the slopes is very good. According Eq. (15) the slopes should be nothing but the rate constants, however, taking into account Eq. (16) they are actually equal to $S_{\mathrm{Zr}}[k(1-\alpha)]$. The recalculation yields

$$
\begin{gathered}
k_{1}=\frac{2.64 \cdot 10^{6}}{(1-0.129) \cdot 0.92}= \\
=3.29 \cdot 10^{6} \mathrm{~kg} \cdot \mathrm{mol}^{-1} \cdot \mathrm{min}^{-1} \cdot \mathrm{cm}^{-2}
\end{gathered}
$$

for the initial Csl melt and

$$
\begin{gathered}
k_{2}=\frac{1.76 \cdot 10^{6}}{(1-0.325) \cdot 0.92}= \\
=2.84 \cdot 10^{6} \mathrm{~kg} \cdot \mathrm{mol}^{-1} \cdot \mathrm{min}^{-1} \cdot \mathrm{cm}^{-2}
\end{gathered}
$$

for the first addition of $\mathrm{KOH}$ to the melt. The average rate constant value can be estimated as $3.07 \cdot 10^{6} \mathrm{~kg} \mathrm{~mol}^{-1} \cdot \mathrm{min}^{-1} \cdot \mathrm{cm}^{-2}$ $\left(S_{n}=0.31 \cdot 10^{6}\right)$ and this value is considerably greater than in the case of using pure zirconium.

The some decrease of the rate constant going from the initial melt to the first $\mathrm{KOH}$ addition can be explained in the terms of uniformity of zirconium surface. In the first turn (the initial melt) the most active surface centers are blocked, whereas after the first addition reaction runs on surface centers of the lower activity.

\section{Conclusions}

So, in the present work we studied the course of the removal of oxide ions from molten Csl by action of galvanic couple "zirconium-platinum" in potentiometric cell with a membrane oxygen electrode $\mathrm{Pt}\left(\mathrm{O}_{2}\right) \mid Y S Z$ which was used for the control of oxide ion concentration. According to the obtained results the efficiency of the galvanic couple is considerably higher than that of pure zirconium.
Concerning the physicochemical features of the experiment it should be noted that the running of deoxidization process is subjected to kinetics of $2^{\text {nd }}$ pseudo-order interaction with respect to $\mathrm{O}^{2-}$, rate constant is ca. $3.07 \cdot 10^{6} \mathrm{~kg} \cdot \mathrm{mol}^{-1} \cdot \mathrm{min}^{-1} \cdot \mathrm{cm}^{-2}$ that is considerably greater than in the case of use of pure zirconium $\left(80 \pm 8 \mathrm{~kg} \cdot \mathrm{mol}^{-1} \cdot \mathrm{min}^{-1} \cdot \mathrm{cm}^{-2}\right)$. The process stops at $p O$ values near 8 $\left(10^{-8} \mathrm{~mol} \cdot \mathrm{kg}^{-1}\right.$ of $\left.\mathrm{O}^{2-}\right)$ and the final concentration of oxide ions is lower than that at the use of $\mathrm{Zr}$ by a factor of $10^{4}$. The effective surface capacity of $\mathrm{Zr}$ in the galvanic couple is estimated as $7.4 \cdot 10^{-5} \mathrm{~mol} \cdot \mathrm{cm}^{-2}$, i.e. it is higher than that of pure $\mathrm{Zr}$ by a factor of 18 .

The practical importance of such an approach for purification of halide melts used for different purposes from oxide ion traces seems very promising for other halide melts formed by cesium,rubidium and potassium salts because of essentially higher enthalpies of formation of the corresponding oxides comparing with that of $\mathrm{ZrO}_{2}$.

Acknowledgement. This work was supported by National Academy of Sciences of Ukraine, project of young scientists No. A52-15 (St. Reg. No.0115U004422).

\section{References}

1. http://www.crystran.co.uk/optical-materials/ caesium-iodide-cesium-iodide-csi.

2. C.Amsler, D.Grogler, W.Joffrain et al., Nucl. Instr. Meth. Phys. Res., Sect.A, 480, 494 (2002).

3. L.N.Trefilova, A.M.Kudin, L.V.Kovaleva et al., Radiat. Meas., 33, 687 (2001).

4. B.G.Zaslavsky, J.Cryst.Growth, 218, 277 (2000).

5. V.L.Cherginets, T.P.Rebrova, Yu.N.Datsko et al., J.Cryst. Growth, 380, 143 (2013).

6. V.L.Balkevich, Techical Ceramics, Stroyizdat, Moscow (1984) [in Russian].

7. A.M.Abdelkader, E.El-Kashif, ISIJ International, 47, 25 (2007).

8. Yu.N.Datsko, T.P.Rebrova, V.L.Cherginets et al., Functional Materials, 21, 307 (2016).

9. V.L.Cherginets, O.V.Demirskaya, T.P.Rebrova, Inorg. Chem., 41, 1045 (2002). 